\title{
Activation of Opioid Receptor Like-1 Receptor in the Spinal Cord Produces Sex-Specific Antinociception in the Rat: Estrogen Attenuates Antinociception in the Female, whereas Testosterone Is Required for the Expression of Antinociception in the Male
}

\author{
Jomo Claiborne, Subodh Nag, and Sukhbir S. Mokha \\ Division of Neurobiology and Neurotoxicology, Department of Biomedical Sciences, Meharry Medical College, Nashville, Tennessee 37208
}

\begin{abstract}
Sex-related differences in the perception and modulation of pain have been reported. The present study is the first to investigate systematically whether activation of opioid receptor-like 1 receptor $\left(\mathrm{ORL}_{1}\right)$ by orphanin $\mathrm{FQ}(\mathrm{OFQ})$ produces sex-specific modulation of spinal nociception and whether estrogen or testosterone contributes to these differences using the rat as an experimental animal. Two behavioral models, the NMDA and heat-induced nociceptive tests, were used to examine sex-specific modulation of spinal nociception. Intrathecal microinjection of $\mathrm{OFQ}$ in male, ovariectomized (OVX), and diestrous rats produced a significant antinociceptive effect on both tests. However, $\mathrm{OFQ}$ failed to produce antinociception in proestrous rats, the phase of the estrous cycle with the highest levels of circulating estradiol, and produced a dose-dependent effect in 0VX females treated with $1 \mathrm{ng}$ to $100 \mu \mathrm{g}$ of estradiol. The antinociceptive effects of OFQ were dose dependent in male and OVX animals and were reversibly antagonized by UFP-101 ([Nphe $\left.{ }^{1}, \operatorname{Arg}^{14}, \mathrm{Lys}{ }^{15}\right] \mathrm{N} /$ $\mathrm{OFQ}(1-13)-\mathrm{NH}_{2}$ ), an $\mathrm{ORL}_{1}$ receptor-selective antagonist. Interestingly, $\mathrm{OFQ}$ was ineffective in gonadectomized (GDX) males, whereas testosterone replacement restored the antinociceptive effect of OFQ in GDX males. We conclude that OFQ produces sex-specific modulation of spinal nociception; estrogen attenuates antinociception in the female in parallel with normal cycling of estrogen levels, and testosterone is required for the expression of antinociception in the male; thus, the sensitivity of the male to the antinociceptive effects of $\mathrm{OFQ}$ is not simply attributable to the intrinsically low estrogen levels in these animals.
\end{abstract}

Key words: orphanin FQ; opioid receptor like-1 receptor; $\mathrm{ORL}_{1}$; sex differences; pain; tail flick; analgesia

\section{Introduction}

Sex-related differences have been reported in the perception and modulation of pain. Women exhibit enhanced sensitivity to experimental pain (for review, see Fillingim and Maixner, 1995) and experience a greater prevalence of pain disorders (Fillingim and Maixner, 1995) (for review, see Berkley, 1997). Sex-related differences in pain modulation by activation of G-proteincoupled receptors such as opioid ( $\mu$ and $\kappa$ ) and $\alpha_{2}$ noradrenergic receptors have been demonstrated in human and animal studies (Gear et al., 1996; Mitrovic et al., 2003; Mogil et al., 2003; Fillingim and Gear, 2004; Nag and Mokha, 2006; Peckham and Traynor, 2006).

The present study focuses on orphanin FQ (OFQ) (Meunier et al., 1995; Reinscheid et al., 1995), an endogenous ligand for the

\footnotetext{
Received June 14, 2006; revised Nov. 9, 2006; accepted Nov. 9, 2006.

This study was supported by National Institutes of Health Grants GM008037, U54 NS041071, RR03032, and MH65782. We thank Dr. Lee E. Limbird for her comments on this manuscript.

Correspondence should be addressed to Dr. Sukhbir S. Mokha, Division of Neurobiology and Neurotoxicology, Department of Biomedical Sciences, Meharry Medical College, 1005 D. B. Todd Boulevard, Nashville, TN 37208. E-mail: smokha@mmc.edu.

DOI:10.1523/JNEUROSCI.4783-06.2006

Copyright $\odot 2006$ Society for Neuroscience $\quad$ 0270-6474/06/2613048-06\$15.00/0
}

opioid receptor-like-1 receptor $\left(\mathrm{ORL}_{1}\right)$ (Bunzow et al., 1994, Mollereau et al., 1994). Although $\mathrm{ORL}_{1}$ shares substantial homology with the classical opioid receptors $(\mu, \delta$, and $\kappa$ ) (Chen et al., 1994; Mollereau et al., 1994), OFQ displays low affinity for the classical opioid receptors, and, reciprocally, agonists of classical opioid receptors display low affinity for the $\mathrm{ORL}_{1}$ receptor (Mollereau et al., 1994; Mogil and Pasternak, 2001).

The $\mathrm{ORL}_{1}$ receptor is expressed in the superficial laminas of the spinal dorsal horn, an area involved in receiving and processing nociceptive information (Bunzow et al., 1994; Mollereau et al., 1994, 1996) (for review, see Mogil and Pasternak, 2001). OFQ has been reported to produce pronociceptive or antinociceptive effects, depending on the route of administration (Meunier et al., 1995; Reinscheid et al., 1995; Erb et al., 1997; Caló et al., 2000). Intracerebroventricular administration of OFQ has been reported to produce (1) hyperalgesia (Meunier et al., 1995; Reinscheid et al., 1995; Wang et al., 1999), (2) hyperalgesia followed by analgesia (Rossi et al., 1996), and (3) reversal of opioidinduced analgesia (Grisel et al., 1996; Mogil et al., 1996; Heinricher et al., 1997; Bertorelli et al., 1999). However, a consensus has emerged that intrathecal application of OFQ into the spinal cord primarily produces analgesia (Xu et al., 1996; King et al., 
1997; Yamamoto and Nozaki-Taguchi, 1997; Yamamoto et al., 1997, 1999; Hao and Ogawa, 1998; Hao et al., 1998; Wang et al., 1999; Yamamoto and Sakashita, 1999) (for review, see Mogil and Pasternak, 2001; Meunier, 2003). Whether activation of ORL $\mathrm{L}_{1}$ in the spinal cord produces sex-specific modulation of nociception remains unknown.

The present investigation was designed to examine whether OFQ produces sex-specific modulation of spinal nociception in the rat using two complementary behavioral measures of nociception: NMDA-induced nociceptive scratching, biting, and licking behavior assay (Aanonsen and Wilcox, 1987) and the noxious heat-induced tail-flick reflex (D'Amour and Smith, 1941). The role of the gonadal steroids estrogen and testosterone in modulating this nociception also was determined.

\section{Materials and Methods}

Animals. The experimental groups consisted of male, female gonadectomized (GDX) male, and ovariectomized (OVX) female Sprague Dawley rats (Harlan Sprague Dawley, Indianapolis, IN). The animals were housed in the Meharry Medical College animal care facility certified by the American Association for the Accreditation of Laboratory Animal Care under a $12 \mathrm{~h}$ light/dark cycle (lights on at 7:00 AM and lights off at 7:00 PM). Food and water were available ad libitum. The experimental protocols were approved by the Institutional Animal Care and Use Committee of Meharry Medical College and abided by the established guidelines of the National Research Council Guide for the Care and Use of Laboratory Animals.

Estrous cycle stages were determined by the standard vaginal smear test. Female rats were operated on in the diestrous (DiE) phase and underwent nociceptive testing after having established two regular ovarian cycles.

Implantation of intrathecal cannulas. Cannulas were implanted in animals under ketamine and xylazine anesthesia (72 and $4 \mathrm{mg} / \mathrm{kg}$, i.p., respectively). The head of the rat was secured in a stereotaxic frame (David Kopf Instruments, Tujunga, CA), and an incision was made above the atlantooccipital membrane, which was cleared to expose the dura. A stretched polyethylene-10 cannula (Intramedic; dead volume, 10 $\mu \mathrm{l}$; Clay Adams, Parsippany, NJ) was inserted into the subarachnoid space through a small slit in the dura. The cannula was gently pushed to a length of $8.5 \mathrm{~cm}$ to reach the lumbosacral enlargement and was secured with dental cement to the base of the skull. The wound was sutured and the animal was placed on a heating blanket until it regained consciousness. Animals were allowed to recover for $5-7 \mathrm{~d}$ before undergoing nociceptive testing. The position of the cannula was confirmed, at the end of testing, by administering $15 \mu \mathrm{l}$ of $2 \%$ lidocaine, which temporarily paralyzed the animal's hindlimbs. Animals showing any neurological impairment were killed immediately.

Estrogen/testosterone replacement. OVX and GDX animals were obtained from Harlan Sprague Dawley and were given a 2 week recovery period before surgical implantation of cannulas. OVX rats that were to receive exogenous estrogen received a single dose of estradiol benzoate ( 1 ng, $10 \mathrm{ng}, 1 \mu \mathrm{g}, 10 \mu \mathrm{g}$, or $100 \mu \mathrm{g} / 100 \mu \mathrm{l}$ sesame oil, s.c.) $48 \mathrm{~h}$ before testing. This regimen (single subcutaneous injection) has been used previously in neuroendocrinology (Berglund et al., 1988; Priest et al., 1995) and in the pain field (Ji et al., 2003, 2005). The rationale for using a $100 \mu \mathrm{g}$ dose of estradiol for most of our experiments was that this dose is known to most reliably induce lordosis behavior in rats (for review, see Clark, 1993a). GDX males to be assessed for the impact of exogenous testosterone were given testosterone propionate $(250 \mu \mathrm{g} / 100 \mu \mathrm{l}$ sesame oil, s.c.) $24 \mathrm{~h}$ before nociceptive testing. This dose of testosterone has been shown to induce maximum copulatory behavior in castrated male rats (Clark, 1993b). Control animal groups received vehicle injections (100 $\mu \mathrm{l}$ of sesame oil, s.c.). At the end of experiments, OVX and GDX animals were randomly operated and inspected for complete removal of gonads. We previously measured serum estradiol concentrations in OVX rats treated with varying doses of estradiol $(\mathrm{OVX}+\mathrm{E})$ and at different time points after injection (Nag and Mokha, 2006). Here we also measured these levels in normally cycling females at proestrous (ProE) and diestrous stages $(63.28 \pm 4.32$ and $32.59 \pm 3.09 \mathrm{pg} / \mathrm{ml}$, respectively; $n=6$ per group). The estrogen levels were found to be within physiological range $48 \mathrm{~h}$ after estradiol injection, the time point when all nociceptive testing is conducted. Furthermore, estradiol levels at this time point after the 100 $\mu \mathrm{g}$ dose of estrogen were similar to that reported previously in normally cycling females at the proestrous stage (Butcher et al., 1974).

OFQ and UFP-101. Three doses of OFQ $(2.5,5$, and $10 \mathrm{nmol} / 10 \mu \mathrm{l}$, i.t. $)$ were administered in separate groups of male and OVX animals, and the effects were examined on the thermal stimulus-induced tail-flick reflex. UFP-101 ([Nphe ${ }^{1}, \operatorname{Arg}^{14}{ }^{14}$ Lys $\left.\left.^{15}\right] \mathrm{N} / \mathrm{OFQ}(1-13)-\mathrm{NH}_{2}\right)(10 \mathrm{nmol} / 5 \mu \mathrm{l}$, i.t.), an $\mathrm{ORL}_{1}$ antagonist, was administered 4 min before administration of OFQ ( $5 \mathrm{nmol} / 10 \mu$ l, i.t.) in male and OVX female rats.

All chemicals were obtained from Sigma (St. Louis, MO) except for UFP-101 (Tocris Cookson, Ballwin, MO).

NMDA-induced nociception. NMDA ( $4 \mathrm{nmol} / 10 \mu \mathrm{l}$ ) (Aanonsen and Wilcox, 1987) was injected into the lumbar spinal cord through the implanted cannulas followed by $10 \mu \mathrm{l}$ of sterile saline. NMDA induced intense scratching/biting/licking behavior that lasted up to $4 \mathrm{~min}$. The number of scratches/bites aimed at the hindlimb area, the latency to scratching behavior, and the duration of the scratching behavior were manually recorded. Higher doses of NMDA resulted in clearly aversive behavior (escape attempts and vocalizations) in pilot experiments and therefore were excluded. OFQ ( $10 \mathrm{nmol} / 10 \mu$ l, i.t. $)$ was administered 10 min before administration of NMDA $(4 \mathrm{nmol} / 10 \mu \mathrm{l})$.

Tail-flick test. Tail-flick latency (TFL) (D’Amour and Smith, 1941) was measured automatically by a tail-flick analgesia meter (model 33T; IITC Life Science, Woodland Hills, CA). Animals were loosely restrained in a Plexiglas cylinder with the dorsal surface of the tail exposed to a radiant heat source mounted $8 \mathrm{~cm}$ above the cylinder. A beam of focused radiant heat was applied 3-7 cm from the tip of the rat's tail; the radiant heat was applied at three separate spots to prevent sensitization as a result of heating the same spot in succession. An automatic cutoff latency of $15 \mathrm{~s}$ was set to prevent tissue damage. Before the tail-flick test, the animals were allowed to acclimate to the restraint cylinder for $15 \mathrm{~min}$. The heat intensity was adjusted to produce a baseline TFL of between 3 and $5 \mathrm{~s}$. Three baseline readings were taken at $2 \mathrm{~min}$ intervals before intrathecal injection of OFQ. TFLs were determined every 2 min for 20 min after injection of OFQ.

Data analysis. Data were analyzed using SPSS software (SPSS, Chicago, IL). All measures were submitted to ANOVA with appropriate betweengroup (sex, drugs) and within-group (time course) factors and dependent variables (number of scratches, latency, duration, TFL). Data obtained in tail-flick studies were submitted to ANOVA corrected for repeated measures. A post hoc (Tukey's) test was performed when necessary for intergroup comparisons. A $p$ value of $<0.05$ was considered significant. Data were plotted as mean \pm SEM.

\section{Results \\ NMDA induces comparable nociceptive behavior in males and females}

To assess whether perception of pain per se differs between sexes, we evaluated whether intrathecal injection of NMDA ( $4 \mathrm{nmol} / 10$ $\mu \mathrm{l}$ ) induces similar scratching behavior in male and female rats. As shown in Figure 1, we observed that the number of scratches (Fig. $1 A$ ) and the duration of scratching behavior (Fig. $1 B$ ) induced by NMDA were comparable for male rats, ovariectomized females, and OVX females treated with estradiol. These findings provide evidence that the perception of pain as measured in our studies does not intrinsically differ between the sexes in the absence of modulators of pain perception, such as antinociceptive agents.

\section{Estrogen-dependent modulation of NMDA-induced nociceptive behavior by OFQ}

The ability of OFQ to diminish NMDA-induced nociception was evaluated in our various experimental groups. OFQ (10 nmol/10 $\mu$ l, i.t.), administered intrathecally $10 \mathrm{~min}$ before NMDA, signif- 
icantly decreased the number of scratches in the male (55\%) and OVX (35\%) groups (Fig. 1A). It also reduced the duration of scratching in the male $(46 \%)$ and OVX $(29 \%)$ groups (Fig. 1 B). In contrast, no significant effects of OFQ were observed on either the number or duration of NMDAinduced scratching behavior in estradioltreated (100 $\mu \mathrm{g} / 100 \mu \mathrm{l}$ sesame oil, s.c.) OVX groups (Fig. 1). These data demonstrate that OFQ failed to produce antinociception in the presence of estrogen and thus reveal dramatic estrogen-dependent modulation of antinociceptive actions.

\section{Estrogen produces dose-dependent} effects on OFQ-induced antinociception To assess the "threshold" of estradiol levels that eliminates the antinociceptive effects of OFQ, the effects of OFQ were tested on NMDA-induced nociceptive behavior in OVX animals treated with estradiol benzoate over a range of $1 \mathrm{ng}$ to $100 \mu \mathrm{g}$ of administered estrogen. As shown in Figure 2, OFQ failed to produce antinociception at $10 \mathrm{ng}$ to $100 \mu \mathrm{g}$ doses of estradiol. The number of scratches or duration of scratching (data not shown) induced by NMDA in OVX animals treated with $10 \mathrm{ng}, 1 \mu \mathrm{g}, 10$ $\mu \mathrm{g}$, or $100 \mu \mathrm{g}$ estradiol did not significantly differ from their respective NMDA-only controls. However, estrogen at the $1 \mathrm{ng}$ dose failed to attenuate the effects of OFQ. OFQ significantly reduced the number of NMDA-induced scratches and duration of scratching (data not shown) at this dose.

Estrogen-dependent modulation of thermal stimulus-evoked tail-flick reflex by OFQ

To determine whether estrogen-dependent modulation of the antinociceptive effects of OFQ were generalizable beyond the intrathecal NMDA-induced scratching behaviors, the effects of OFQ were tested on the thermal stimulus evoked tail-flick reflex. Predrug baseline TFLs were comparable (3-5 s) among male, OVX, OVX+E, ProE, and DiE groups (Fig. 3), confirming that the intrinsic perception of pain did not differ among our experimental groups. OFQ, given intrathecally at time $0 \mathrm{~min}$, produced a significant increase in the TFL in male and OVX groups (Fig. $3 A$ ), whereas injection of vehicle did not. The effects of OFQ appeared within 2-4 min after injection, peaked at 6-10 min, and persisted for $>20 \mathrm{~min}$. In contrast, OFQ failed to significantly alter the TFL in the OVX +E group (Fig. 3A).

It was important to establish whether or not these dramatic effects of estrogen to prevent the antinociceptive effects of OFQ would be relevant in the context of the varying estrogen levels that accompany the estrous cycle in rats. Thus, we assessed whether OFQ produces estrogen-dependent modulation of nociception in normally cycling females during phases of high (proestrous) or low (diestrous) estrogen. As shown in Figure 3B, OFQ significantly increased TFL in DiE females but not in ProE animals. These are important findings, because they demonstrate that the in vivo cycling of estrogen levels in female animals is sufficient to alter response to the antinociceptive effects of OFQ, although our control studies indicate that the intrinsic perception of pain is not altered in cycling female rats not exposed to antinociceptive agents (see baseline).
A

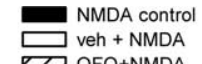
$\square$ veh + NMDA B
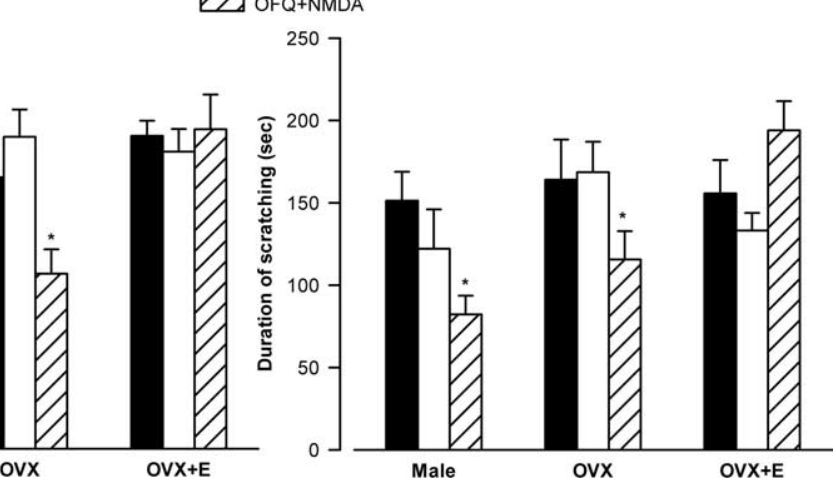

Figure 1. Intrathecal OFQ administration significantly reduces the NMDA-induced behavior in male and OVX rats. NMDA (4 $\mathrm{nmol} / 10 \mu \mathrm{l})$ injection resulted in scratching behavior ( $\boldsymbol{A}$, number of scratches; $\boldsymbol{B}$, duration of scratching) that was comparable $<$, yielded significant main effects of group and drug on the number of scratches and duration (minimum $F_{(2,43)}=4.46 ; p<0.02$ ) as an interaction between these two factors $\left(F_{(4,43)}=5.47\right.$ for scratches and 3.75 for duration; $\left.p<0.02\right)$. Post hoc analysis (veh + NMDA)]. Furthermore, the number and duration of NMDA-induced scratching in OVX+E animals given OFQ remained significantly higher compared with the male and OVX groups given OFQ (all post hoc $p<0.05$ ). ${ }^{*} p<0.05$.

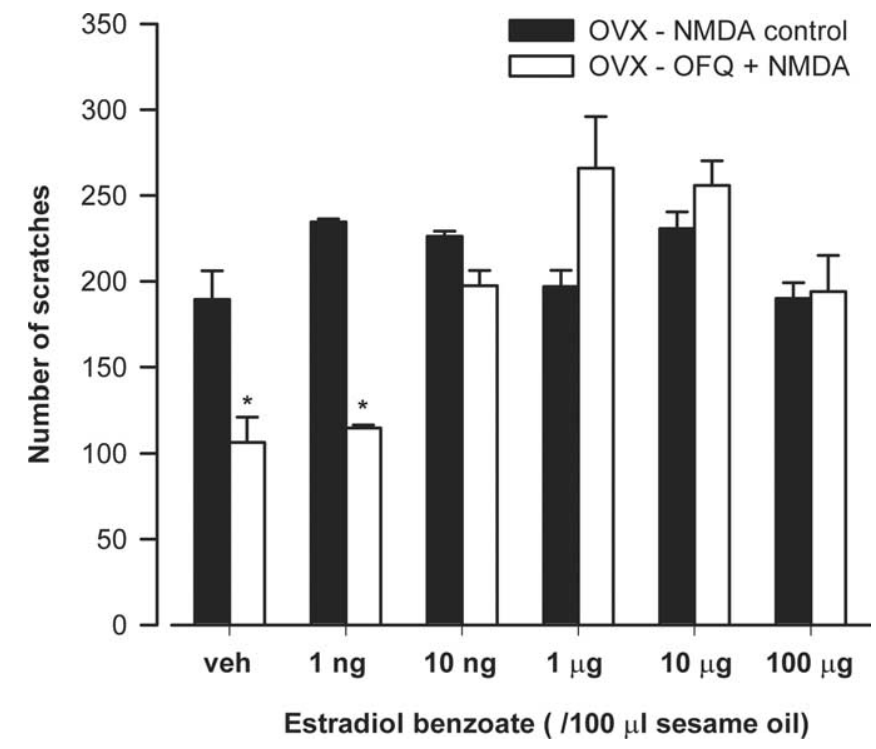

Figure 2. Estrogen attenuates the antinociceptive effect of OFQ in OVX females only at high doses (10 ng, $1 \mu \mathrm{g}, 10 \mu \mathrm{g}$, or $100 \mu \mathrm{g}$ ) but not at the lowest dose (1 ng). Significant main effects of estrogen dose on NMDA-induced scratches $\left(F_{(11,70)}=10.69 ; p<0.01\right)$ and duration $\left(F_{(11,70)}=3.89 ; p<0.01\right.$; data not shown) were obtained on ANOVA. Post hoc test revealed that, although OFO significantly reduced the number of NMDA-induced scratches in OVX animals treated with vehicle (sesame oil) and $1 \mathrm{ng}$ of estradiol, it failed to reduce it in other groups given higher doses of estradiol (10 ng to $100 \mu \mathrm{g}$ ). ${ }^{*} p<0.01$ compared with NMDA control.

\section{The effects of OFQ are dose dependent}

To assess whether the antinociceptive effect of OFQ is dose dependent, we evaluated the impact of increasing doses of OFQ $(2.5,5$, and $10 \mathrm{nmol})$ on tail-flick latency. OFQ did not alter TFL at the lowest dose evaluated $(2.5 \mathrm{nmol}$ ) (Fig. $4 A$ ) but did so at higher doses. Moreover, the highest dose of OFQ tested (10 $\mathrm{nmol}$ ) produced an immediate maximal increase in TFL compared with $5 \mathrm{nmol}$, which reached the maximal antinociceptive effect in both males and OVX females. 
A

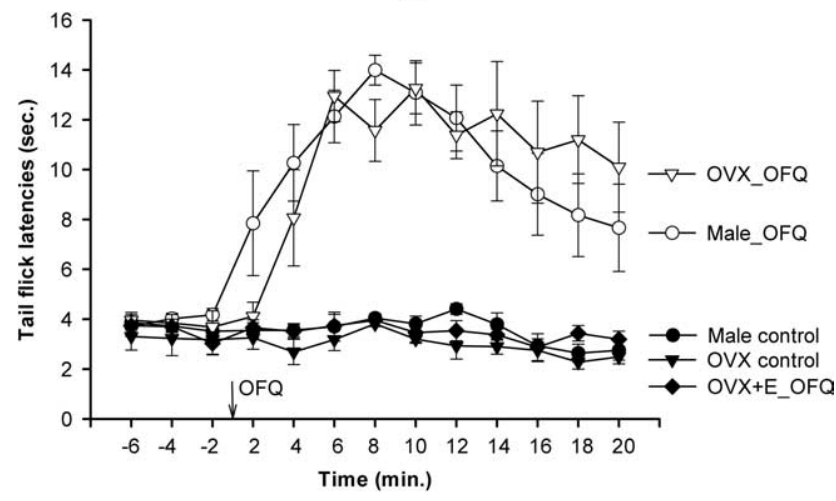

B

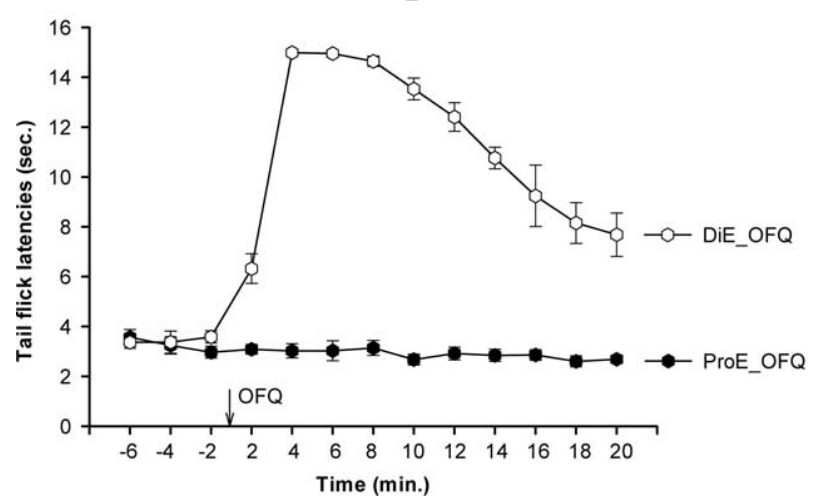

Figure 3. OFQ reduces thermal nociception in male, DiE, and OVX animals but not in proestrous or $\mathrm{OVX}+\mathrm{E}$ rats. $A$, The baseline tail-flick latencies in all groups were comparable. A repeated-measures ANOVA yielded significant main effects of time $\left(F_{(12,216)}=8.98 ; p<0.01\right)$ and group $\left(F_{(4,18)}=12.97 ; p<0.01\right)$. Post hoc comparisons indicated that $0 \mathrm{FQ}$ (given at time $0 \mathrm{~min}$ ) produced significant increases in tail-flick latencies starting at time $4 \mathrm{~min}$ in male and OVX groups compared with the baseline latencies or their respective vehicle-treated controls (all $p<0.05$ ). This antinociceptive effect of $0 \mathrm{FQ}$ persisted for up to $20 \mathrm{~min}$. In contrast, the effects of $\mathrm{OFQ}$ were not seen in the estradiol-treated $\mathrm{OVX}+\mathrm{E}$ group. $\boldsymbol{B}$, In normally cycling females, $0 F Q$ significantly increased the TFL at DiE but not at ProE stage. Repeated-measures AVOVA showed a significant main effect of time $\left(F_{(12,84)}=68.85 ; p<0.01\right)$ and group $\left(F_{(1,7)}=368 ; p<0.01\right)$. Post hoc comparisons revealed that, although OFQ significantly increased TFL in the DiE group at all time points after intrathecal administration (all $p<0.01$ ), it had no effect in the ProE group, and the TFL after OFQ remained similar to baseline latencies. Postinjection TFL did not differ from baseline TFL in any group, and there were no significant main effects of time $\left(F_{(12,120)}=1.31 ; \mathrm{NS}\right)$ or group $\left(F_{(3,10)}<1 ; \mathrm{NS}\right)$

\section{An antagonist selective for the $\mathrm{ORL}_{1}$ receptor blocks the} antinociceptive effects of OFQ

To determine whether the $\mathrm{ORL}_{1}$ receptor mediated or contributed to the antinociceptive effects produced by OFQ, we examined the effect of pretreatment of animals with UFP-101, a selective $\mathrm{ORL}_{1}$ receptor antagonist, on changes in tail-flick latency produced by OFQ. UFP-101 (10 nmol/5 $\mu$ l, i.t.) administered 4 min before OFQ completely blocked the antinociceptive effect of OFQ in the male and OVX groups and restored TFL to the baseline levels (Fig. 4 B). In contrast, UFP-101 administered alone did not result in any significant change in TFL from baseline. These data are consistent with the interpretation that activation of the $\mathrm{ORL}_{1}$ receptor is involved in the antinociceptive effects of OFQ evaluated in these studies.

Testosterone is required for the expression of the antinociceptive effects of OFQ in male rats

To determine whether testosterone plays a role in the antinociceptive effects of OFQ in the male, experiments were conducted

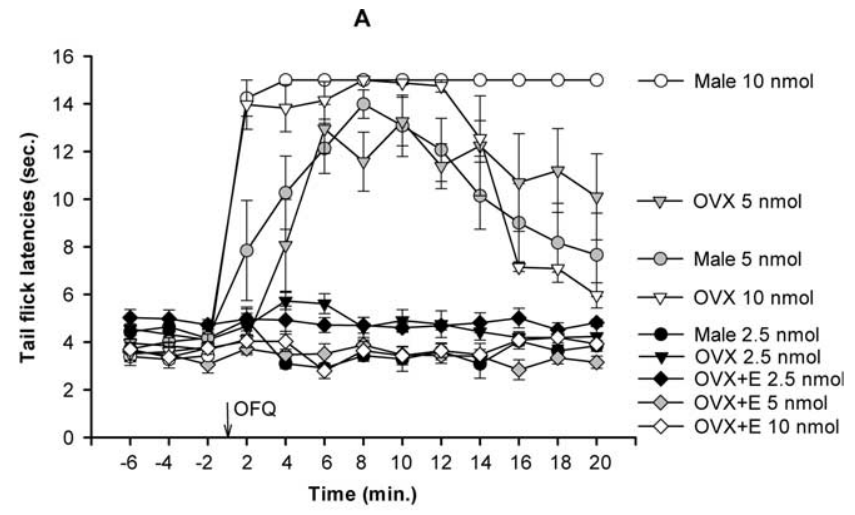

B

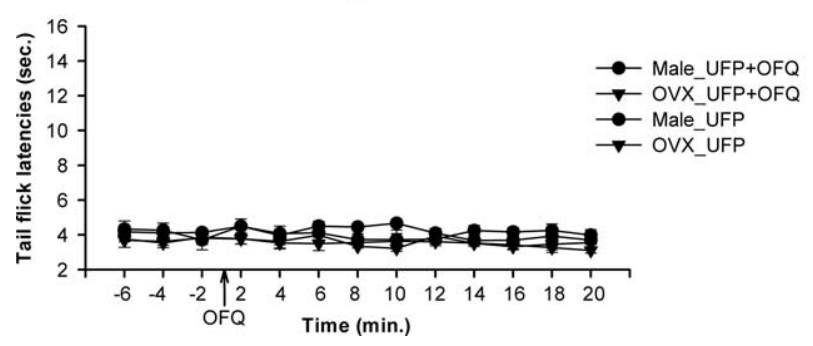

Figure 4. $\quad A, O F Q$ produces dose-dependent antinociceptive effects in male and OVX rats. A dose-response study revealed that OFQ significantly increased the TFL in male and OVX groups at 5 and $10 \mathrm{nmol}$ doses but not at $2.5 \mathrm{nmol}$. In contrast, effects of $0 \mathrm{FQ}$ were not seen regardless of its dose in the OVX+E group. ANOVA yielded significant main effects of time $\left(F_{(12,444)}=\right.$ $51.49 ; p<0.01)$, group $\left(F_{(2,37)}=47.93 ; p<0.01\right)$, and OFQ dose $\left(F_{(2,37)}=36.31 ; p<0.01\right)$ and an interaction between the latter two $\left(F_{(4,37)}=17.03 ; p<0.01\right)$. Post hoc comparisons revealed that $\mathrm{OF} Q$ had significantly increased the TFL in male and OVX groups only and at doses of 5 and $10 \mathrm{nmol}$ compared with baseline. It did not alter the TFL in all groups at the $2.5 \mathrm{nmol}$ dose and in the OVX+E group regardless of the dose (all $p<0.05)$. B, UFP- $101(10 \mathrm{nmol} / 5 \mu \mathrm{l}$, i.t.), an $\mathrm{ORL}_{1}$ receptor antagonist, given 4 min before $\mathrm{OFQ}$ completely abolished the antinociceptive effects of $\mathrm{OF} Q$ in male and $\mathrm{OVX}$ groups.

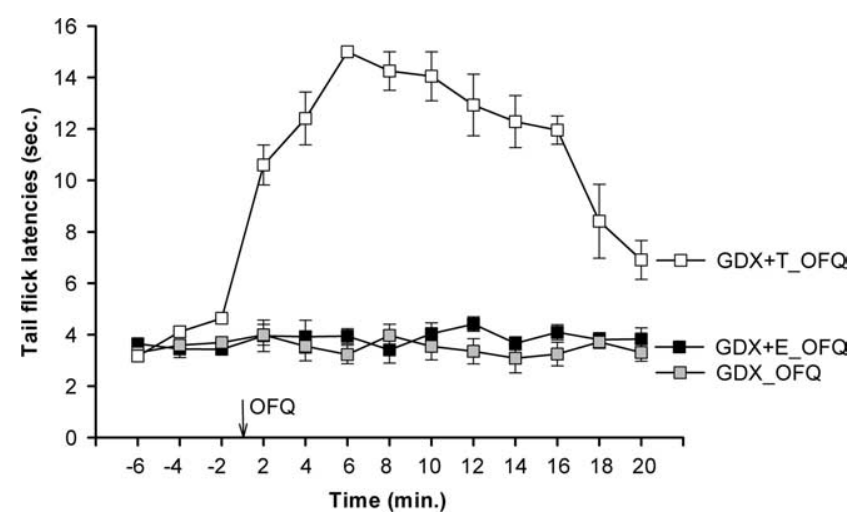

Figure 5. Testosterone is required for the expression of the antinociceptive effect in the male. OFQ failed to produce antinociception in gonadectomized males. Testosterone replacement in GDX males (GDX $+\mathrm{T}$ ) restored the antinociceptive effects of OFQ. Overall ANOVA indicated a significant main effect of time $\left(F_{(12,204)}=21.99 ; p<0.01\right)$ and group $\left(F_{(3,17)}=\right.$ 220.97; $p<0.01)$. Post hoc comparisons revealed that, although OFQ did not alter TFL in GDX and GDX + E groups, it significantly increased the TFL in the GDX + T group at postinjection time points $2-20 \min$ (all $p<0.05$ ).

on GDX males, testosterone-treated GDX males, and estrogentreated GDX males. Gonadectomy in males eliminated the antinociceptive effects of OFQ (Fig. 5). However, testosterone replacement in GDX males $24 \mathrm{~h}$ before behavioral testing restored the antinociceptive effects produced by OFQ. 
For the purposes of comparison with our studies in the female, we examined whether estrogen $(100 \mu \mathrm{g} / 100 \mu \mathrm{l})$ administered to GDX males would alter the effect of OFQ in these animals (Fig. 5). It was of interest, but perhaps predictable, that administration of estrogen to GDX males did not alter the lack of ability of OFQ to produce antinociception in GDX males. The effect of estrogen in intact males was not tested because estrogen is known to inhibit testosterone synthesis.

\section{Discussion}

This study is the first to demonstrate two important findings regarding sex-dependent response to antinociceptive agents. First, we demonstrated that estrogen attenuates the antinociceptive effect produced by OFQ activation in the spinal cord in the female and that this regulation by estrogen occurs in response to changes in endogenous estrogen that occur normally in estrous cycle in the female. Second, OFQ-induced antinociception in the male requires testosterone to be present, which demonstrates that the pronounced antinociceptive response to OFQ in the male is not simply a reflection of the absence of estrogen, or low levels of estrogen, in these animals. These results have considerable importance for the design and administration of antinociceptive agents to be used in women, postmenopausal women, and aging men.

The current findings with the NMDA-induced nociception are consistent with our previous observations in the trigeminal system (Flores et al., 2001), which showed that OFQ reduced the NMDA-evoked responses of trigeminal nociceptive neurons and NMDA-induced nociceptive behavior in male and OVX animals. However, the present study advances those previous findings in four important ways. First, the present study used a dose-response study with lower doses ( $1 \mathrm{ng}, 10 \mathrm{ng}, 1 \mu \mathrm{g}, 10 \mu \mathrm{g}$, and 100 $\mu \mathrm{g})$ of estrogen that achieve circulating levels of estradiol that mimic the physiological range (Nag and Mokha, 2006), whereas the previous study used a single high dose of estrogen $(400 \mu \mathrm{g})$ (Flores et al., 2001). Second, the present study explored the contribution of the $\mathrm{ORL}_{1}$ receptor in mediating the antinociceptive effects of OFQ. Third, the present study included a natural stimulus-induced thermal nociceptive test to complement the NMDA-induced nociceptive test. Fourth, the present study also revealed the important role of testosterone in mediating the antinociceptive effects of OFQ in the male.

There were no differences in the basal nociception, i.e., NMDA-induced nociceptive behavior or baseline tail-flick latencies before drug treatment was similar between sexes. This could be attributable to the intense nature of the noxious stimuli (NMDA or thermal) used in the present study. Similarly, the fact that UFP-101, an $\mathrm{ORL}_{1}$ receptor antagonist, did not have an effect on nociception by itself, could also be attributable to the suprathreshold acute thermal stimulus used. The subtle differences in basal nociception as well as antinociception produced by endogenously released OFQ may require mild nociceptive stimuli and will need additional investigation that is beyond the scope of the present study.

Our finding that OFQ is antinociceptive in males is consistent with the evidence provided in previous electrophysiological and behavioral studies (Stanfa et al., 1996; Xu et al., 1996; Henderson and McKnight, 1997; Lai et al., 1997; Liebel et al., 1997; Meunier, 1997; Harrison and Grandy, 2000) (for review, see Mogil and Pasternak, 2001). Our data, however, as indicated above, indicate that this response of males is not simply attributable to the absence of estrogen but rather relies specifically on the availability of testosterone.

The estrogen dose-response study in the present investigation revealed an "all-or-none" effect of estrogen, i.e., estrogen either completely abolished the antinociceptive effect of OFQ (10 ng to $100 \mu \mathrm{g}$ doses) or it failed to do so (1 ng dose). Such dose-related all-or-none effects of estrogen have also been observed on visceral nociception in the spinal cord (Ji et al., 2003, 2005).

There are a number of possible molecular mechanisms via which estrogen might diminish OFQ-induced antinociception, including decreasing the expression of the $\mathrm{ORL}_{1}$ receptor (Flores et al., 2003) and/or its coupling to G-proteins (for review, see Kelly and Wagner, 1999; Malyala et al., 2005), which would secondarily modify the affinity of OFQ to the $\mathrm{ORL}_{1}$ receptor. Estrogen receptors $(\mathrm{ER} \alpha / \mathrm{ER} \beta)$ are present in spinal dorsal horn neurons (Amandusson et al., 1996, 1999; Shughrue et al., 1997), and estrogen, in addition to altering the expression of opioid peptides (Medina et al., 1993; Micevych et al., 1997; Amandusson et al., 1999; Micevych and Sinchak, 2001) (for review, see Craft et al., 2004), has also been shown by us and others to alter the expression of the $\mathrm{ORL}_{1}$ receptor gene and protein in the trigeminal region and the hypothalamus (Sinchak et al., 1997; Flores et al., 2003; Sinchak et al., 2006).

Reciprocally, the requirement for testosterone in mediating the antinociceptive effects of OFQ in the male could be attributable to upregulating expression of the $\mathrm{ORL}_{1}$ gene or enhancing coupling of OFQ receptors to $\left(\mathrm{G}_{\mathrm{i}} / \mathrm{G}_{\mathrm{o}}\right)$ proteins and thus to downstream effectors.

Our novel findings about the importance of physiological levels of estrogen in cycling females modulating the antinociceptive response to OFQ and the requirement of testosterone for manifesting the antinociceptive response to OFQ in males represent important new insights into the design and administration of antinociceptive agents in cycling women, postmenopausal women, and aging men.

\section{References}

Aanonsen LM, Wilcox GL (1987) Nociceptive action of excitatory amino acids in the mouse: effects of spinally administered opioids, phencyclidine and sigma agonists. J Pharmacol Exp Ther 243:9-19.

Amandusson A, Hermanson O, Blomqvist A (1996) Colocalization of oestrogen receptor immunoreactivity and preproenkephalin mRNA expression to neurons in the superficial laminae of the spinal and medullary dorsal horn of rats. Eur J Neurosci 8:2440-2445.

Amandusson A, Hallbeck M, Hallbeck AL, Hermanson O, Blomqvist A (1999) Estrogen-induced alterations of spinal cord enkephalin gene expression. Pain 83:243-248.

Berkley KJ (1997) Sex differences in pain. Behav Brain Sci 20:371-380.

Berglund LA, Derendorf H, Simpkins JW (1988) Desensitization of brain opiate receptor mechanisms by gonadal steroid treatments that stimulate luteinizing hormone secretion. Endocrinology 122:2718-2726.

Bertorelli R, Corradini L, Rafiq K, Tupper J, Calo G, Ongini E (1999) Nociceptin and the ORL-1 ligand [Phelpsi (CH2-NH)Gly2]nociceptin(113) $\mathrm{NH} 2$ exert anti-opioid effects in the Freund's adjuvant-induced arthritic rat model of chronic pain. Br J Pharmacol 128:1252-1258.

Bunzow JR, Saez C, Mortrud M, Bouvier C, Williams JT, Low M, Grandy DK (1994) Molecular cloning and tissue distribution of a putative member of the rat opioid receptor gene family that is not a mu, delta or kappa opioid receptor type. FEBS Lett 347:284-288.

Butcher RL, Collins WE, Fugo NW (1974) Plasma concentration of LH, $\mathrm{FSH}$, prolactin, progesterone and estradiol-17beta throughout the 4-day estrous cycle of the rat. Endocrinology 94:1704-1708.

Caló G, Guerrini R, Rizzi A, Salvadori S, Regoli D (2000) Pharmacology of nociceptin and its receptor: a novel therapeutic target. Br J Pharmacol 129:1261-1283.

Chen Y, Fan Y, Liu J, Mestek A, Tian M, Kozak CA, Yu L (1994) Molecular cloning, tissue distribution and chromosomal localization of a novel member of the opioid receptor gene family. FEBS Lett 347:279-283.

Clark JT (1993a) Analysis of female sexual behavior: proceptivity, receptivity, and rejection. In: Methods in neurosciences (Conn PM, ed), pp 5475. San Diego: Academic. 
Clark JT (1993b) Component analysis of male sexual behavior. In: Methods in neurosciences (Conn PM, ed), pp 32-53. San Diego: Academic.

Craft RM, Mogil JS, Aloisi AM (2004) Sex differences in pain and analgesia: the role of gonadal hormones. Eur J Pain 8: 397-411.

D'Amour FE, Smith DL (1941) A method for determining loss of pain sensation. J Pharmacol Exp Ther 72:74-79.

Erb K, Liebel JT, Tegeder I, Zeilhofer HU, Brune K, Geisslinger G (1997) Spinally delivered nociceptin/orphanin FQ reduces flinching behaviour in the rat formalin test. NeuroReport 8:1967-1970.

Fillingim RB, Gear RW (2004) Sex differences in opioid analgesia: clinical and experimental findings. Eur J Pain 8:413-425.

Fillingim RB, Maixner W (1995) Gender differences in the response to noxious stimuli. Pain Forum 4:209-221.

Flores CA, Wang XM, Zhang KM, Mokha SS (2001) Orphanin FQ produces gender-specific modulation of trigeminal nociception: behavioral and electrophysiological observations. Neuroscience 105:489-498.

Flores CA, Shughrue P, Petersen SL, Mokha SS (2003) Sex-related differences in the distribution of opioid receptor-like 1 receptor mRNA and colocalization with estrogen receptor mRNA in neurons of the spinal trigeminal nucleus caudalis in the rat. Neuroscience 118:769-778.

Gear RW, Miaskowski C, Gordon NC, Paul SM, Heller PH, Levine JD (1996) Kappa-opioids produce significantly greater analgesia in women than in men. Nat Med 2:1248-1250.

Grisel JE, Mogil JS, Belknap JK, Grandy DK (1996) Orphanin FQ acts as a supraspinal, but not a spinal, anti-opioid peptide. NeuroReport 7:2125-2129.

Hao JX, Xu IS, Wiesenfeld-Hallin Z, Xu XJ (1998) Anti-hyperalgesic and antiallodynic effects of intrathecal nociceptin/orphanin FQ in rats after spinal cord injury, peripheral nerve injury and inflammation. Pain 76:385-393.

Hao S, Ogawa H (1998) Naltrexone, but not atropine or yohimbine, antagonizes suppression of formalin-induced spinal sensitization by intrathecal nociceptin. Life Sci 63:PL167-PL173.

Harrison LM, Grandy DK (2000) Opiate modulating properties of nociceptin/orphanin FQ. Peptides 21:151-172.

Heinricher MM, McGaraughty S, Grandy DK (1997) Circuitry underlying antiopioid actions of orphanin FQ in the rostral ventromedial medulla. J Neurophysiol 78:3351-3358.

Henderson G, McKnight AT (1997) The orphan opioid receptor and its endogenous ligand-nociceptin/orphanin FQ. Trends Pharmacol Sci 18:293-300.

Ji Y, Murphy AZ, Traub RJ (2003) Estrogen modulates the visceromotor reflex and responses of spinal dorsal horn neurons to colorectal stimulation in the rat. J Neurosci 23:3908-3915.

Ji Y, Tang B, Traub RJ (2005) Modulatory effects of estrogen and progesterone on colorectal hyperalgesia in the rat. Pain 117:433-442.

Kelly MJ, Wagner EJ (1999) Estrogen modulation of G-protein-coupled receptors. Trends Endocrinol Metab 10:369-374.

King MA, Rossi GC, Chang AH, Williams L, Pasternak GW (1997) Spinal analgesic activity of orphanin FQ/nociceptin and its fragments. Neurosci Lett 223:113-116.

Lai CC, Wu SY, Dun SL, Dun NJ (1997) Nociceptin-like immunoreactivity in the rat dorsal horn and inhibition of substantia gelatinosa neurons. Neuroscience 81:887-891.

Liebel JT, Swandulla D, Zeilhofer HU (1997) Modulation of excitatory synaptic transmission by nociceptin in superficial dorsal horn neurones of the neonatal rat spinal cord. Br J Pharmacol 121:425-432.

Malyala A, Kelly MJ, Ronnekleiv OK (2005) Estrogen modulation of hypothalamic neurons: activation of multiple signaling pathways and gene expression changes. Steroids 70:397-406.

Medina VM, Dawson-Basoa ME, Gintzler AR (1993) $17 \beta$-estradiol and progesterone positively modulate spinal cord dynorphin: relevance to the analgesia of pregnancy. Neuroendocrinology 58:310-315.

Meunier JC (1997) Nociceptin/orphanin FQ and the opioid receptor-like ORL1 receptor. Eur J Pharmacol 340:1-15.

Meunier JC (2003) Utilizing functional genomics to identify new pain treatments: the example of nociceptin. Am J Pharmacogenomics 3:117-130.

Meunier JC, Mollereau C, Toll L, Suaudeau C, Moisand C, Alvinerie P, Butour JL, Guillemot JC, Ferrara P, Monsarrat B (1995) Isolation and structure of the endogenous agonist of opioid receptor-like ORL1 receptor. Nature 377:532-535.

Micevych P, Sinchak K (2001) Estrogen and endogenous opioids regulate CCK in reproductive circuits. Peptides 22:1235-1244.

Micevych PE, Eckersell CB, Brecha N, Holland KL (1997) Estrogen modu- lation of opioid and cholecystokinin systems in the limbic-hypothalamic circuit. Brain Res Bull 44:335-343.

Mitrovic I, Margeta-Mitrovic M, Bader S, Stoffel M, Jan LY, Basbaum AI (2003) Contribution of GIRK2-mediated postsynaptic signaling to opiate and alpha2-adrenergic analgesia and analgesic sex differences. Proc Natl Acad Sci USA 100:271-276.

Mogil JS, Pasternak GW (2001) The molecular and behavioral pharmacology of the orphanin FQ/nociceptin peptide and receptor family. Pharmacol Rev 53:381-415.

Mogil JS, Grisel JE, Reinscheid RK, Civelli O, Belknap JK, Grandy DK (1996) Orphanin FQ is a functional anti-opioid peptide. Neuroscience 75:333-337.

Mogil JS, Wilson SG, Chesler EJ, Rankin AL, Nemmani KV, Lariviere WR, Groce MK, Wallace MR, Kaplan L, Staud R, Ness TJ, Glover TL, Stankova M, Mayorov A, Hruby VJ, Grisel JE, Fillingim RB (2003) The melanocortin-1 receptor gene mediates female-specific mechanisms of analgesia in mice and humans. Proc Natl Acad Sci USA 100:4867-4872.

Mollereau C, Parmentier M, Mailleux P, Butour JL, Moisand C, Chalon P, Caput D, Vassart G, Meunier JC (1994) ORL1, a novel member of the opioid receptor family. Cloning, functional expression and localization. FEBS Lett 341:33-38.

Mollereau C, Simons MJ, Soularue P, Liners F, Vassart G, Meunier JC, Parmentier M (1996) Structure, tissue distribution, and chromosomal localization of the prepronociceptin gene. Proc Natl Acad Sci USA 93:8666-8670.

Nag S, Mokha SS (2006) Activation of alpha(2)-adrenoceptors in the trigeminal region produces sex-specific modulation of nociception in the rat. Neuroscience 142:1255-1262.

Peckham EM, Traynor JR (2006) Comparison of the antinociceptive response to morphine and morphine-like compounds in male and female Sprague-Dawley rats. J Pharmacol Exp Ther 316:1195-1201.

Priest CA, Vink KL, Micevych PE (1995) Temporal regulation by estrogen of beta-preprotachykinin mRNA expression in the rat ventromedial nucleus of the hypothalamus. Brain Res Mol Brain Res 28:61-71.

Reinscheid RK, Nothacker HP, Bourson A, Ardati A, Henningsen RA, Bunzow JR, Grandy DK, Langen H, Monsma Jr FJ, Civelli O (1995) Orphanin FQ: a neuropeptide that activates an opioidlike $\mathrm{G}$ protein-coupled receptor. Science 270:792-794.

Rossi GC, Leventhal L, Pasternak GW (1996) Naloxone sensitive orphanin FQ-induced analgesia in mice. Eur J Pharmacol 311:R7-R8.

Shughrue PJ, Lane MV, Merchenthaler I (1997) Comparative distribution of estrogen receptor-alpha and -beta mRNA in the rat central nervous system. J Comp Neurol 388:507-525.

Sinchak K, Hendricks DG, Baroudi R, Micevych PE (1997) Orphanin FQ/ nociceptin in the ventromedial nucleus facilitates lordosis in female rats. NeuroReport 8:3857-3860.

Sinchak K, Romeo HE, Micevych PE (2006) Site-specific estrogen and progestin regulation of orphanin $\mathrm{FQ} /$ nociceptin and nociceptin opioid receptor mRNA expression in the female rat limbic hypothalamic system. J Comp Neurol 496:252-268.

Stanfa LC, Chapman V, Kerr N, Dickenson AH (1996) Inhibitory action of nociceptin on spinal dorsal horn neurones of the rat, in vivo. Br J Pharmacol 118:1875-1877.

Wang JL, Zhu CB, Cao XD, Wu GC (1999) Distinct effect of intracerebroventricular and intrathecal injections of nociceptin/orphanin FQ in the rat formalin test. Regul Pept 79:159-163.

Xu XJ, Hao JX, Wiesenfeld-Hallin Z (1996) Nociceptin or antinociceptin: potent spinal antinociceptive effect of orphanin $\mathrm{FQ} /$ nociceptin in the rat. NeuroReport 7:2092-2094.

Yamamoto T, Nozaki-Taguchi N (1997) Effects of intrathecally administered nociceptin, an opioid receptor-likel receptor agonist, and $N$-methyl-Daspartate receptor antagonists on the thermal hyperalgesia induced by partial sciatic nerve injury in the rat. Anesthesiology 87:1145-1152.

Yamamoto T, Sakashita Y (1999) The role of the spinal opioid receptor likel receptor, the NK-1 receptor, and cyclooxygenase- 2 in maintaining postoperative pain in the rat. Anesth Analg 89:1203-1208.

Yamamoto T, Nozaki-Taguchi N, Kimura S (1997) Analgesic effect of intrathecally administered nociceptin, an opioid receptor-like1 receptor agonist, in the rat formalin test. Neuroscience 81:249-254.

Yamamoto T, Nozaki-Taguchi N, Sakashita Y, Kimura S (1999) Nociceptin/ orphanin FQ: role in nociceptive information processing. Prog Neurobiol 57:527-535. 